\title{
Using Cell Cross-section Dimensions and Digital Image Correlation to Evaluate Drying Shrinkage and Collapse in Eucalyptus Nitens Wood
}

\author{
Alan Dickson * and Bernard Dawson
}

\begin{abstract}
An approach combining maps of wood morphology and digital image correlation was developed to investigate the drying of Eucalyptus nitens wood. Maps of morphological features (vessel and ray distribution) and cell cross-section dimensions were acquired by confocal laser scanning microscopy. Shrinkage maps were generated using digital image correlation. There were statistically significant correlations between shrinkage/collapse and wood morphology at two levels. Firstly, there were positional relationships, with for example, both radial and tangential shrinkage increasing with increasing distance from vessel elements. Secondly, there were dimensional relationships, such as, cells with large perimeters (relative to their wall thickness) on average showing greater shrinkage. Generally, the positional relationships dominated the dimensional relationships. Detailed analysis over large areas allows for a fuller analysis of the interrelationship between wood morphology and drying shrinkage and collapse.
\end{abstract}

Keywords: Wood drying; Wood shrinkage and collapse; Digital image correlation; Wood morphology; Confocal microscopy; Eucalyptus nitens

Contact information: Scion, Te Papa Tipu Innovation Park, 49 Sala Street, Rotorua 3010, Private Bag 3020, Rotorua 3046, New Zealand; *Corresponding author: alan.dickson@scionresearch.com

\section{INTRODUCTION}

Upon drying, Eucalyptus nitens (Maiden) wood is prone to cracking and internal checking, limiting its utilisation for timber applications. This is due to high levels of differential cell collapse (deformation) and shrinkage (Blackburn et al. 2010). The role of wood structure in shrinkage and collapse has received extensive interest over the years, but the causality remains unclear. Several studies on Eucalytus point to a relationship between high levels of checking and low wood density (McKenzie et al. 2003; Rebolledo et al. 2013), but the correlations are generally low and may be related to a higher frequency of vessels (Rebolledo et al. 2013). Checking (Lausberg et al. 1995; Shelbourne et al. 2002) and collapse (Ananías et al. 2014) in E. nitens can be more prevalent in the middle growth rings. However, McKenzie et al. (2003) saw no significant relationship between checking and ring number or cell microfibril angle or cell dimensions. Likewise, they saw no relationship between density (between earlywood and latewood) and collapse (McKenzie et al. 2003). According to Kube and Raymond (2005) tree diameter and basic density were the best predictors of collapse but only explained $31 \%$ of it.

Wood rays are often linked with collapse. Wu et al. (2006) showed a positive correlation between residual collapse (collapse above the fibre saturation point) and the proportion of ray material. They hypothesized that increased proportions of ray parenchyma, in species susceptible to collapse, may make a greater contribution to the generation of collapse than other anatomical features and would be regarded as one of the 
main indicators of cell collapse intensity. According to Bariska (1992), collapsed fibres were generally found in contact with rays (or in rays) and not with vessels.

Most work investigating drying/shrinkage/swelling in relationship to wood morphology has been on softwoods with a focus on earlywood and latewood. Earlywood and latewood respond differently during drying (and swelling) with latewood tending to show the greatest overall response. Earlywood shrinkage is generally anisotropic, with tangential much greater than radial shrinkage. Latewood shrinkage is generally more isotropic (Boutelje 1962; Perré and Hubber 2007; Derome et al. 2011, 2013; Almeida et al. 2014; Lanvermann et al. 2014; Perré et al. 2016). There is also an interaction between earlywood and latewood affecting total shrinkage behaviour (Murata et al. 2001; Patera et al. 2018). The two tissues have a restraining influence on each other, making the combined shrinkage more isotropic (Patera et al. 2018). This appears to be a more complex relationship than where tangential shrinkage remains approximately constant from earlywood to latewood and radial shrinkage increases from earlywood to latewood (Perré et al. 2007; Almeida et al. 2014).

Variation in collapse between latewood and earlywood is often cited as a cause of internal checking and/or washboarding in sawn eucalypt timber (Hamilton et al. 2009). In E. nitens the checks are primarily located in the earlywood, have a lenticular shape, and are oriented in the radial direction (Rebolledo et al. 2013). In Eucalyptus regnans, earlywood is generally more collapse-susceptible than latewood. This is because earlywood fibres often have similar external diameters to latewood fibres but are generally thinner-walled. Thus, latewood fibres are more resistant to internal water tension than earlywood fibres and cell collapse occurs when cell walls are not strong enough to withstand the greater internal tension (Innes 1996). Han et al. (2016) used digital image correlation (DIC) to investigate moisture related shrinkage. They found slightly higher shrinkage values for latewood than earlywood but both had the expected trend of tangential shrinkage being greater than radial.

Numerous studies have applied DIC to wood drying and swelling, whether at the tissue level (earlywood and latewood) (Derome et al. 2013; Lanvermann et al. 2014; Han et al. 2016) or over larger areas (Bigorgne et al. 2011; Kang et al. 2016; Lee and Jeong 2018). With the exception of the work in oak by Badel et al. (2001, 2006), little of the DIC related literature deals with the anatomy of hardwoods in relationship to wood drying. In a study looking at shrinkage in oak wood, both the properties of individual cells, and the gross wood morphology, were needed to predict shrinkage (Badel et al. 2007). It was noted that some of the deviations from the predicted model behaviour were due to the presence of cell collapse and reaction tissue.

Most previous studies have either dealt with gross variations in wood morphology over large regions, or detailed analysis over very small regions. This study presents the first steps to bridge the gap between these two scales by combining cell and tissue level observations. It is hypothesised that the exposed cell cross-section dimensions will show some relationship with the drying deformation of the bulk wood underneath and that local drying responses (small regions) will be influenced by more global responses (larger regions). These relationships were investigated to determine their relative influences and to inform analyses over larger size scales. Ultimately, this approach can be used to understand the relationship between drying deformation at the cell level and wood anatomy/morphology at macro scales up to several centimetres or greater. 


\section{EXPERIMENTAL}

\section{Overview}

Confocal laser microscopy was used to image part of the transverse surface of $E$. nitens wood $(12 \times 12 \times 12 \mathrm{~mm}$ cubes $)$ before and after drying. Images were stitched together and covered an area $>3 \mathrm{~mm}^{2}$. DIC was applied to the resultant images to obtain maps of shrinkage. Image analysis was used to obtain maps of the cell dimensions. Statistical correlation analysis was used to analyse the relationship between shrinkage and cell dimensions (Fig. 1).

\section{Preparation of Samples}

Two cubes of $12 \times 12 \times 12 \mathrm{~mm}$ were cut from the same piece of green (wet), approximately 14 year old $E$. nitens heartwood. They came from adjacent positions in the height dimension of the tree (the top surface of one was close to the bottom surface of the other) (Fig. 2). The transverse surfaces were prepared with a Leica SM2010R sliding microtome (Leica Biosystems, Nussloch, Germany). A central region of $4 \times 4 \mathrm{~mm}$ was marked-out on one transverse surface and by following the grain on the radial and tangential surfaces. The equivalent region was marked out on the other transverse surface. These central regions were imaged and did not contain growth rings.

\section{Drying}

The air-dried sample was kept in a controlled temperature $\left(25^{\circ} \mathrm{C}\right)$ and humidity (65\% relative humidity) for 3 weeks. The oven-dried sample was in an oven at $105{ }^{\circ} \mathrm{C}$ for 2 days.

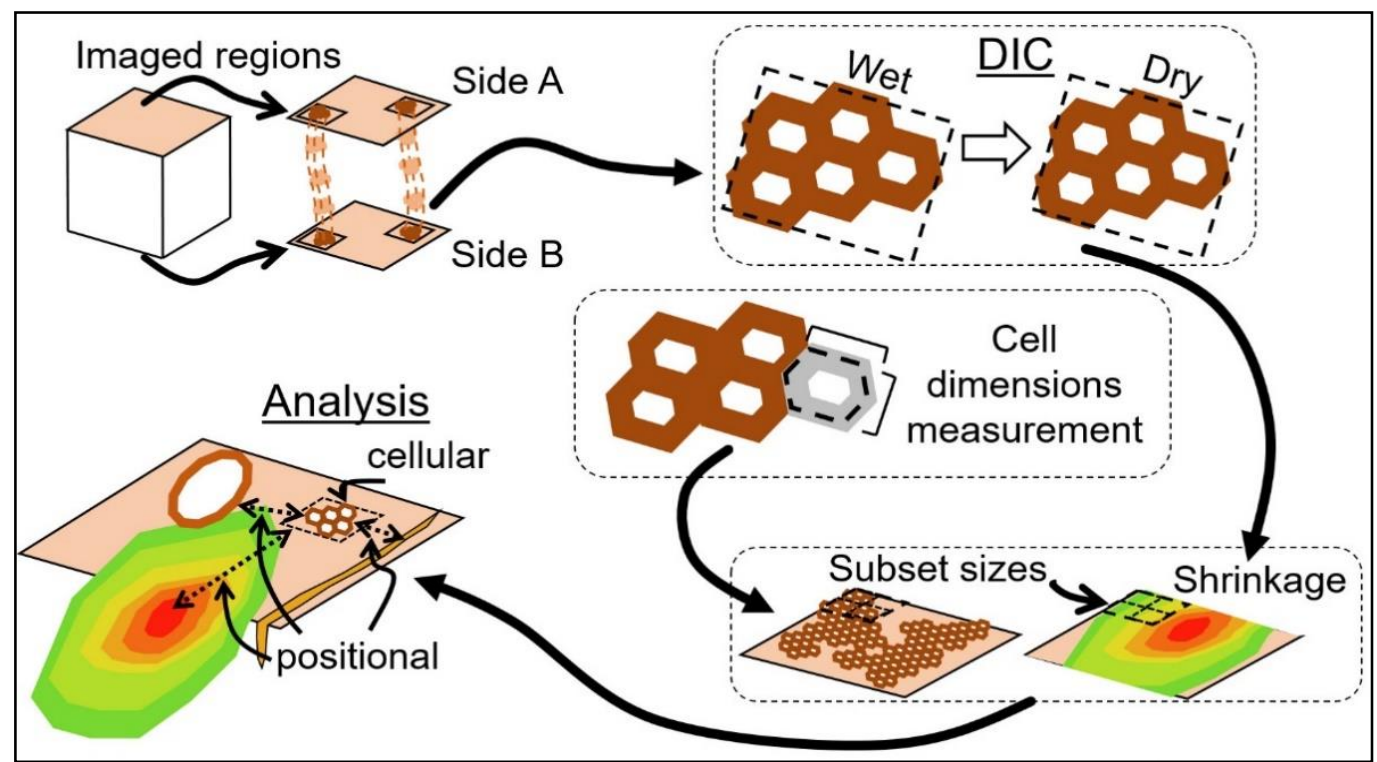

Fig. 1. Overview of approach taken

\section{Imaging}

To avoid drying during imaging, the wet cubes were immersed in water (in a small container) to just below the surface to be imaged. A few drops of $0.0002 \%$ safranin stain was added to aid imaging. A no. 1.5 cover glass was on the surface of the cube. A Leica SP5 II confocal laser scanning microscope (CLSM) (Leica Microsystems, Mannheim, 
Germany), a 20× objective lens and $2 \times$ zoom $(2048 \times 2048$ pixels, giving a pixel size of $0.189 \mu \mathrm{m}$ ) were used. Type F immersion oil (Leica Biosystem, Wetzler, Germany) was used (between cover glass and lens). The excitation wavelength was $488 \mathrm{~nm}$, and emission was detected in the 500 to $700 \mathrm{~nm}$ range.

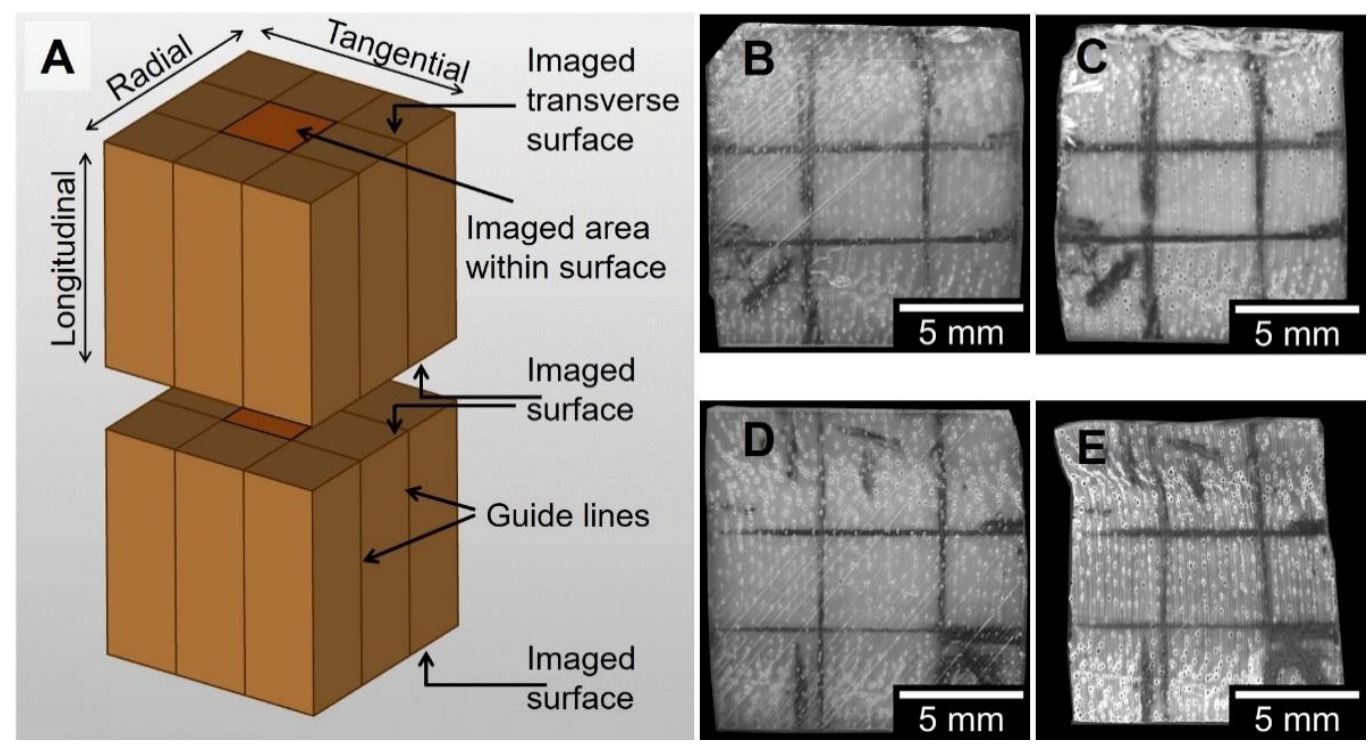

Fig. 2. Overview of cubes. A) geometry of the 2 sample cubes used $(\sim 12 \times 12 \times 12 \mathrm{~mm})$. B) cube before and C) after air-drying. D) cube before and E) after oven-drying

For dried cubes, type F immersion oil was placed directly on the transverse surface followed by a no. 1.5 cover glass. This was required for imaging. The same microscope settings and configuration as above were used.

Multiple images (80 to 90) were gathered from the surfaces using $20 \%$ overlap. Images were stitched together using Image Composite Editor (Version 2.0.3.0, Microsoft Corporation). The stitching of one image set (oven-dried sample) was visually compared to a manual stitching using MosaicJ (Thévenaz et al. 2007) and was regarded as being satisfactory and representative.

Low magnification images (pixel size $=10 \mu \mathrm{m}$ ) were also gathered of each face of each cube using a Leica MZ12 microscope (Leica Microsystems, Wetzler, Germany) fitted with a Leica EC3 digital camera (Leica Microsystems, Singapore). Imaging was done on the wet samples then after drying (to measure gross dimensional changes due to drying) then again after the addition of the immersion oil (to measure gross dimensional changes due to the oil). Each edge of the six faces of the cubes was measured.

\section{DIC}

VIC 2D version 2009.1.0 (Correlated Solutions Inc., Irmo, SC, USA) was used. To map strain on to the original (wet) cell dimensions, the wet image was regarded as the deformed image (dry to wet). The sign of the resultant strain data was reversed to obtain negative strain (wet to dry, = shrinkage). For clarity, the data are presented as the percentage of radial and tangential shrinkage. Two different subset sizes were used: a) 100 $\mu \mathrm{m}$ subset with a step-size of $3 \mu \mathrm{m}$; and b) $400 \mu \mathrm{m}$ subset with a step-size of $10 \mu \mathrm{m}$. The subset size controlled the area used to track displacements and the step-size controlled the spacing between points analysed during the correlation. Lagrangian finite strain was used. 
Shear strain was also measured and analysed, but as it showed intermediate trends between radial and tangential shrinkage this data was not presented.

\section{Image Processing and Analysis}

The image analysis of cell dimensions was only performed on the undeformed, wet surfaces. All image processing and analysis was performed using ImageJ 1.52i (Fiji) (Schneider et al. 2012). The two transverse surfaces of a cube were aligned on a 'bestguess' based on position in the imaged region and similarities of vessel arrangement. Images were contrast enhanced using the local area contrast enhancement (CLAHE plugin (Saalfeld 2010)) with a $13 \mu \mathrm{m}$ block size followed by unsharp mask filtering. The Huang method was used for thresholding and binarizing followed by three iterations of erosion and dilation. Size filtering was applied to remove very small and very large cells (vessel elements). Circularity filtering was applied to remove irregularly shaped cells (poorly imaged cells and ray cells). The resident Voronoi plugin was used to find the cell perimeter by determining the midpoints between adjacent cell lumens (Dickson et al. 2017). The cell and lumen perimeters of 84 randomly selected cells were traced manually and compared to the same binarized cells. The relationship between the binarized and manually measured cell dimensions was good with an $\mathrm{R}^{2}$ of 0.85 for cell perimeter and 0.94 for lumen perimeter. Individual cell dimensions were calculated as shown in Fig. 3.

The individual cell dimensions were then mapped back on to the original image (a map of cell wall thickness, wall area etc.). The binarized image (white = cell walls, black = lumens) was regarded as being proportional to density. Vessel lumens and ray cells were identified manually, and the resident Euclidian Distance Map plugin was used to generate distance maps to the nearest vessels and rays respectively. The cell cross-section dimensions, density and distance maps were then averaged over areas comparable with the subset and step sizes of the strain maps $(100 \times 100$ and $400 \times 400 \mu \mathrm{m})$. Vessels, rays and missing cells were not included in the averaging. An overview of the images used for image analysis is shown in Fig. 4.

Cell-ray contacts were estimated by taking a single tangential image of the air-dried sample (after drying). The image was approximately $3.1 \times 3.1 \mathrm{~mm}$. A single transverse line was drawn across the middle of the image (transverse orientation), and every cell that crossed the line (excluding vessels) was examined along the cell's length to determine if it came into direct contact with a ray.

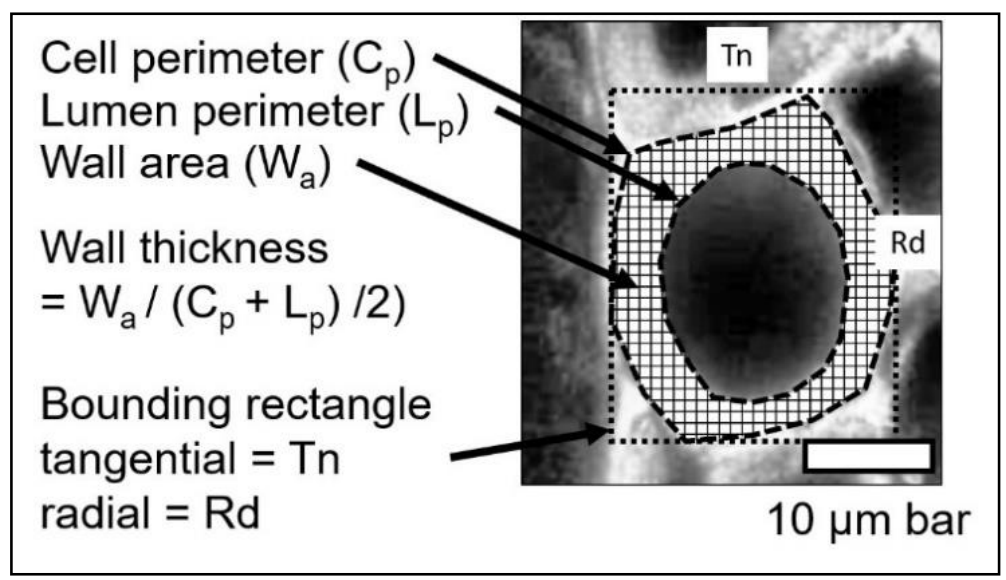

Fig. 3. Measured cell cross-section dimensions 


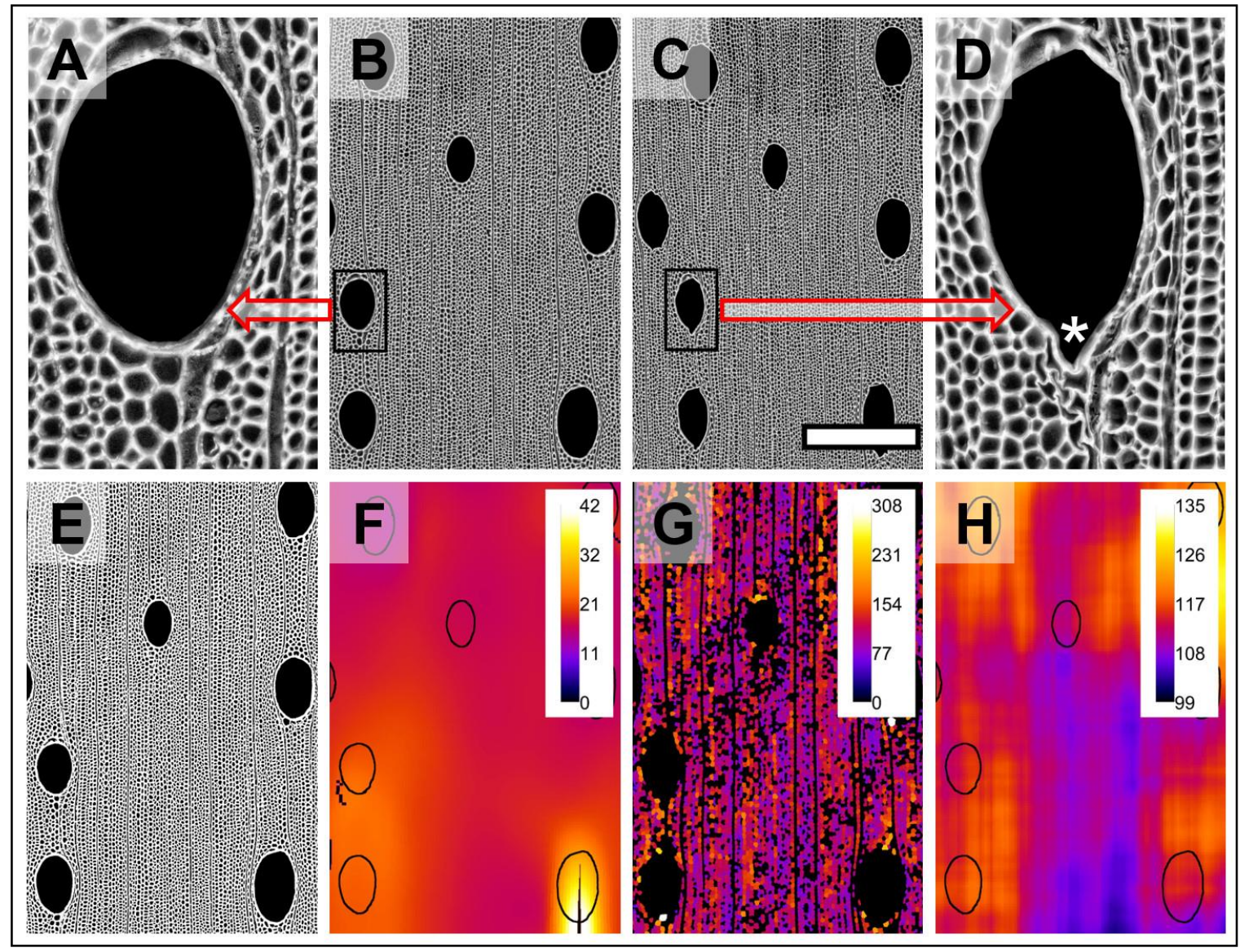

Fig. 4. Image comparisons. A) and B) green (wet) sample. C) and D) Oven-dried sample. Scale bar $=400 \mu \mathrm{m}$. Some cell collapse is visible in paratracheal parenchyma below the vessel element ${ }^{*}$ ). E) Binarised image. F) Colour-coded percentage tangential shrinkage (green to dry). G) Individual cell cross-section data (in this case colour-coded for cell wall area). H) Colour-coded wall area averaged over $400 \mu \mathrm{m}$ diameter

\section{Statistical Analysis of Strain and Cell Dimension Maps}

Statistical analysis was performed using $\mathrm{R}$ version 3.6.0 (RStudio version 1.2.1355). Matching point by point data was extracted from images with the spacing between sample points matching the subset size $(100$ and $400 \mu \mathrm{m})$. The 'rcorr' function (Hmisc version 4.2-0) was used to determine the Pearson product-moment and Spearman correlation coefficients (significance level, $\alpha=0.05$ ). Both the Pearson and Spearman coefficients measure the strength of a correlation, but the Pearson correlation is a parametric test measuring linearity. The Spearman coefficient is a non-parametric, rankbased test that does not require linearity (Hauke and Kossowski 2011). Rank-based multiple regression was performed using the 'rFit' package 0.23.0 (Kloke and McKean 2012). Partial Spearman correlation coefficients were calculated using the 'ppcor' package 1.1 (Kim 2015). Either point by point data from both surfaces of each cube ( $\mathrm{n}$ of surface A $+n$ of surface $B=2 n)$ or the average of both surfaces $(2 n / 2=n)$ were used. The ShapiroWilk test ('shapiro.test' function) was used to assess normality of the data. In most cases the strain data was found to be significantly non-normal (an appropriate transformation was not found). 


\section{RESULTS AND DISCUSSION}

As expected, the oven-dried cube showed significantly greater radial and tangential shrinkage than the air-dried cube (Fig. 5). The addition of immersion oil (required for the imaging of the dried samples) did not have a significant effect on the gross dimensions. Therefore, it was assumed there was no effect at the microscopic level. Images of the airdried cube didn't show any obvious signs of cell collapse; thus, this cube was regarded as exhibiting mainly shrinkage. In contrast, the oven-dried cube did show obvious signs of cell deformation/collapse.

After drying there was some distortion (Fig. 4D) of fibres and paratracheal parenchyma compared to the green state (Fig. 4A). Some vessel elements also became more elliptical in shape. This sample was regarded as exhibiting collapse and shrinkage. Green, air-dried cubes can collapse but to a reduced level compared to oven-dried green samples. Air-drying is a much slower process allowing time for much of the drying stresses arising to be dissipated. Also, the lower temperature of air-drying $\left(25^{\circ} \mathrm{C}\right)$ reduces both the amount and the rate of internal water tension development as moisture loss from the water column is slower. No obvious checking was seen in either cube.

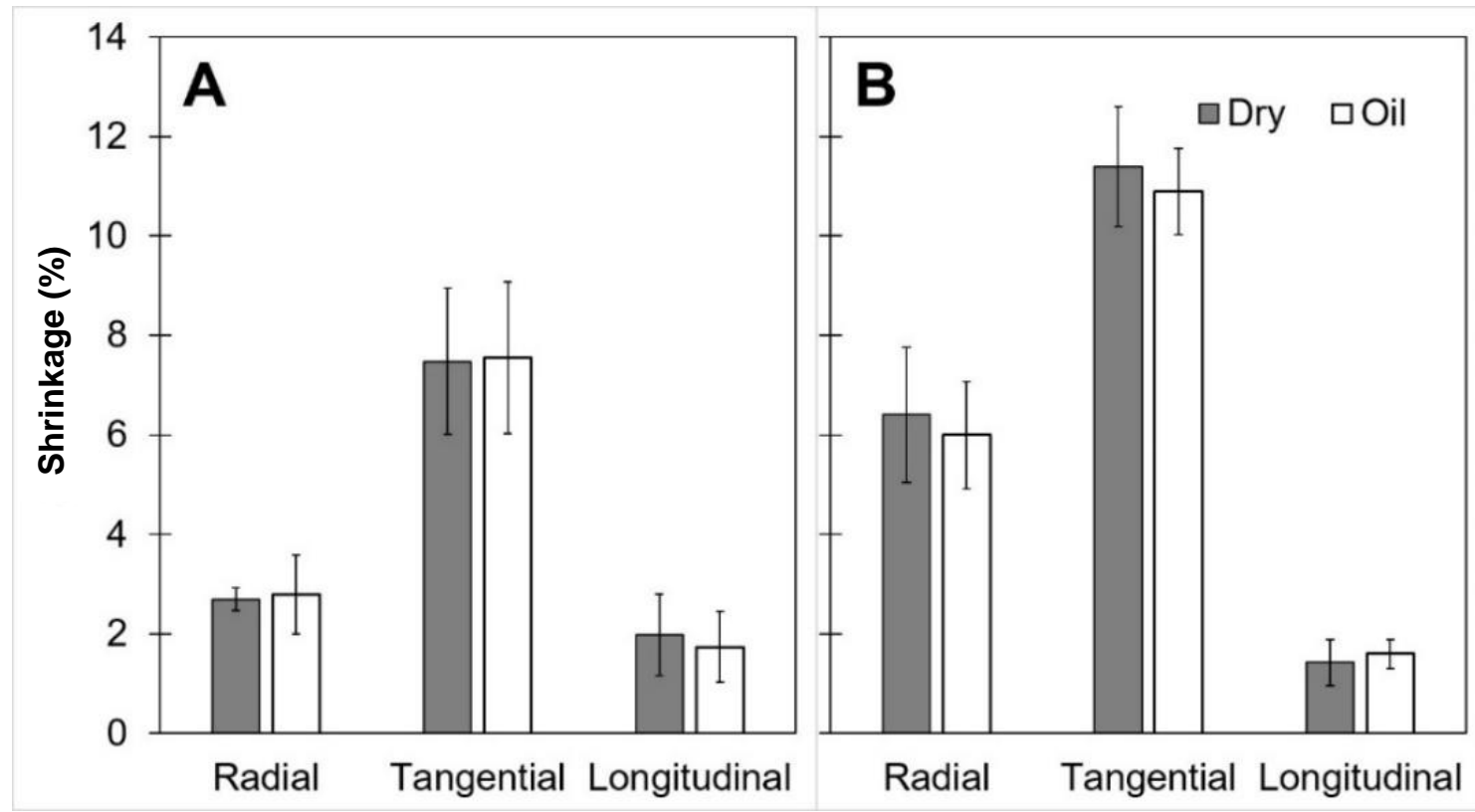

Fig. 5. Shrinkage of cubes after drying (dry) and after the addition of immersion oil required for CLSM imaging (oil). A) Air-dried cube. B) Oven-dried cube. Error bars show 95\% confidence intervals, $n=8$ replicate measurements of each face.

After image matching, DIC, and accounting for poorly imaged areas the imaged areas were trimmed to $\sim 2.4 \times 1.3 \mathrm{~mm}($ tangential $\times$ radial $)\left(\sim 3.1 \mathrm{~mm}^{2}\right)$ and $\sim 1.9 \times 2.8 \mathrm{~mm}$ $\left(\sim 5.3 \mathrm{~mm}^{2}\right)$ for the air-dried and oven-dried samples respectively. The shrinkage data extracted for the point by point analyses are shown in Fig. 6 . The data contained numerous outliers and the distributions were non-normal. The measured cell dimensions and distances prior to drying are shown in Table 1. 


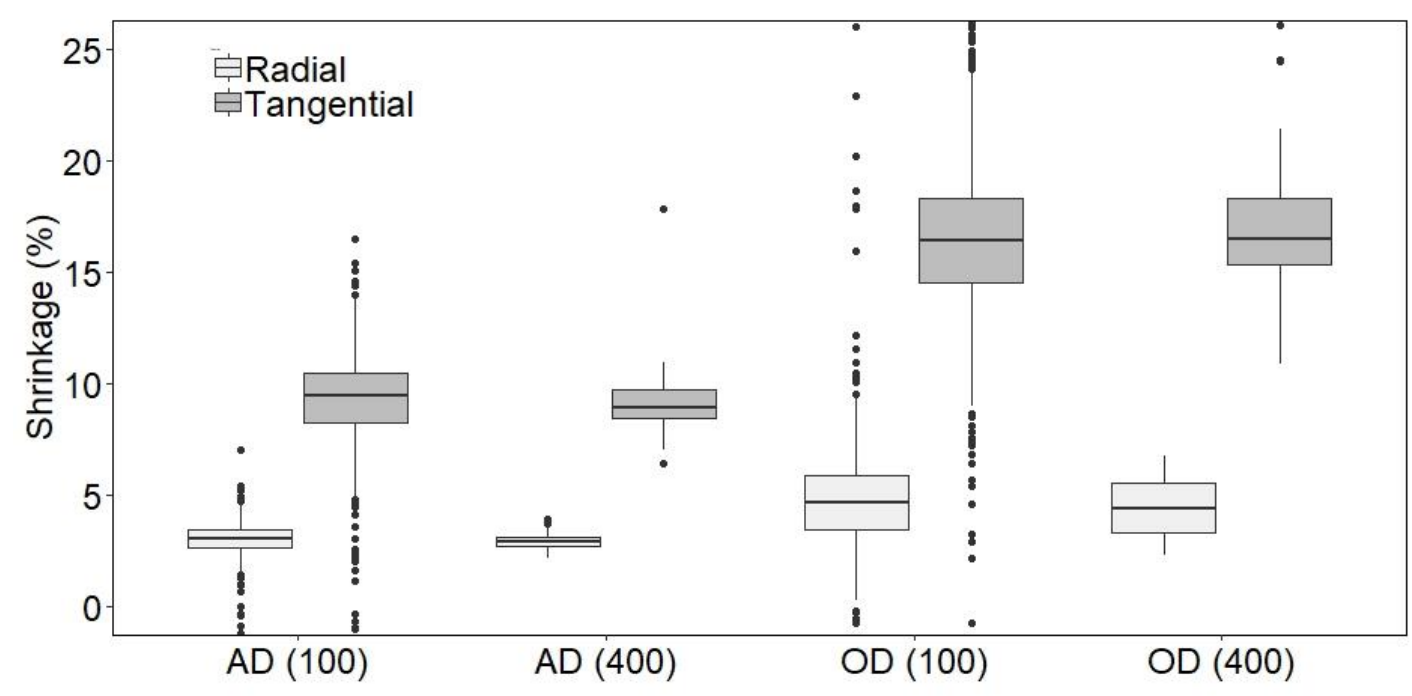

Fig. 6. Box plots of shrinkage data extracted from the DIC strain maps for the air-dried (AD) and oven-dried (OD) cubes at 100 and $400 \mu \mathrm{m}$ subset size averaging. The lower and upper bounds of the box are the 25 and 75 percentiles respectively. The central line is the median. The whiskers extend to $1.5 \times$ the interquartile range. Dots represent outliers.

Table 1. Summary Data of Cell Dimensions and Distances (Prior to Drying) Measured by Image Analysis

\begin{tabular}{|c|c|c|c|c|}
\hline & \multicolumn{2}{|c|}{$\begin{array}{c}\text { Air-dried, } \\
\mathrm{n}=21042\end{array}$} & $\begin{array}{c}\text { Oven-dried, } \\
\mathrm{n}=44738\end{array}$ \\
\hline & mean & s.d. & mean & s.d. \\
\hline Cell perimeter, $\mu \mathrm{m}$ & 55 & 8 & 54 & 8 \\
\hline Lumen perimeter, $\mu \mathrm{m}$ & 35 & 6 & 34 & 6 \\
\hline Wall area, $\mu \mathrm{m}^{2}$ & 108 & 26 & 108 & 27 \\
\hline Wall thickness, $\mu \mathrm{m}$ & 2 & 0 & 2 & 0 \\
\hline Cell diameter, $\mu \mathrm{m}$ & 17 & 2 & 17 & 2 \\
\hline & \multicolumn{5}{|c|}{ Both cubes } \\
\hline Distance measures, $\mathrm{n}=4$ & \multicolumn{3}{|c|}{ mean } & \multicolumn{2}{|c|}{2} \\
\hline Mean distance to a ray cell, $\mu \mathrm{m}$ & \multicolumn{7}{|c|}{26} \\
\hline Mean distance to a vessel element, $\mu \mathrm{m}$ & \multicolumn{7}{|c|}{154} & \multicolumn{3}{c|}{} \\
\hline
\end{tabular}

\section{Comparison of Transverse Faces}

In this section the two faces of the cubes are compared to investigate the correlations between them.

The degree of correlation ( $r$ ) between the measured features of the two sides of a given cube was generally low (Fig. 7). Most correlations (and all significant ones) were positive indicating the two sides were not fully independent of each other, as expected. Wood anatomy tends to vary less longitudinally than radially. For example, data in Groom et al. (2002) show mean tracheid cross-sectional area (in Pinus taeda) varied about the same amount radially as in $10 \times$ the distance longitudinally. Similarly, this was seen in $E$. globulus for fibre length longitudinally (Ridoutt and Sands 1993) and radially (Carrillo et al. 2015). Thus, it is expected that longitudinally adjacent cells of the same type would be similar. 

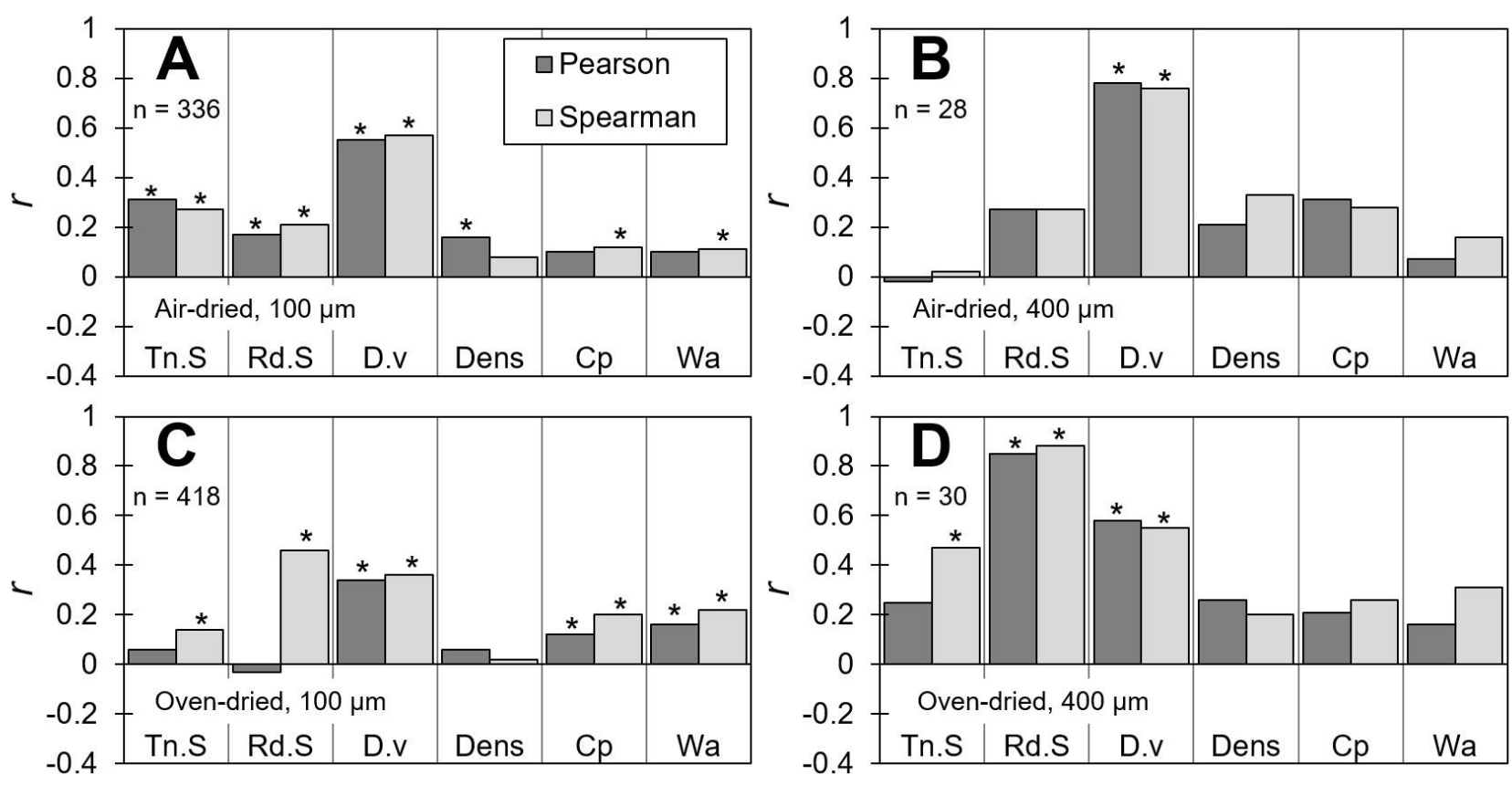

Fig. 7. Pearson and Spearman correlations between the two imaged surfaces of the A) air-dried block, $100 \mu \mathrm{m}$ subset. B) air-dried block, $400 \mu \mathrm{m}$ subset. C) oven-dried block, $100 \mu \mathrm{m}$ subset. D) oven-dried block, $400 \mu \mathrm{m}$ subset. * indicates significant correlation coefficients (>95\% confidence) $. \mathrm{Tn} . \mathrm{S}=$ tangential shrinkage, $\mathrm{Rd} . \mathrm{S}=$ radial shrinkage, $\mathrm{D} . \mathrm{v}=$ distance to vessel, Dens $=$ density, $\mathrm{Cp}=$ cell perimeter, $\mathrm{Wa}=$ cell wall area .

The relative distance to a vessel showed a high correlation between sides, as this was the basis of the best guess alignment. The value of $r$ often varied according to subset size and whether the Pearson or Spearman coefficient was used. Situations where the Spearman coefficient was much larger than the Pearson (oven-dried, $100 \mu \mathrm{m}$, radial shrinkage - Fig. 7C) likely indicate that the relationship is ranked-based (similarly ordered) but non-linear.

Given the non-normal distribution of the of the shrinkage data, only the rank-based Spearman correlation will be presented from this point onwards. Averaging over the larger subset size $(400 \mu \mathrm{m})$ also generally gave the largest $r$ values. This is due to a reduction in the scatter of the data and the effective suppression of outliers. As there is a degree of correlation between the two transverse faces, it is likely they are representative of the bulk of the tissue within.

\section{Correlations with Shrinkage}

In this section the DIC data and image analysis data are compared to determine correlations between wood shrinkage and measured wood morphological parameters.

At the cellular level, individual cell collapse was visible in the oven-dried cube (Fig. 4C, D). It is generally accepted that cells that have been cut cannot fully develop hydrostatic tensions leading to cell collapse (Redman et al. 2016; Dawson et al. 2020). Thus, the cell collapse visible on the cut surfaces is not directly related to the features of that specific cell but is more likely the result of tensions developed in cells beneath the cut surface. In this respect the $r$ values of correlations from the mean of the two faces was generally greater than simply combining the two faces (data not shown). Given that longitudinal variation in cell morphology is relatively stable (see above), it could be 
expected that the mean of the shrinkage expressed at the two transverse faces was representative of the shrinkage occurring within the bulk of the woody material.

There was a relationship between shrinkage and position within the cube surface (Fig. 8). The correlation between radial position and shrinkage was particularly strong for the oven-dried cube and showed opposite trends for tangential and radial shrinkage. For the air-dried sample there was no significant relationship between radial and tangential shrinkage (or the ratio of tangential/radial) related to radial position. Therefore, it is unlikely that the relative change in radial and tangential shrinkage in the oven-dried sample is due to local changes in cell morphology related to a radial progression from earlywood to latewood. Instead, it is more likely a local consequence of a more global phenomenon. Visually, total collapse was greatest out of the imaged region, towards the bark (increasing radial position). As this region of collapse was only visible after drying, no strain or cell dimension data were available. Tangential shrinkage increased, and radial shrinkage decreased closer to this region of strong collapse. It was inferred that the measured shrinkage gradient is a consequence of greater collapse elsewhere.
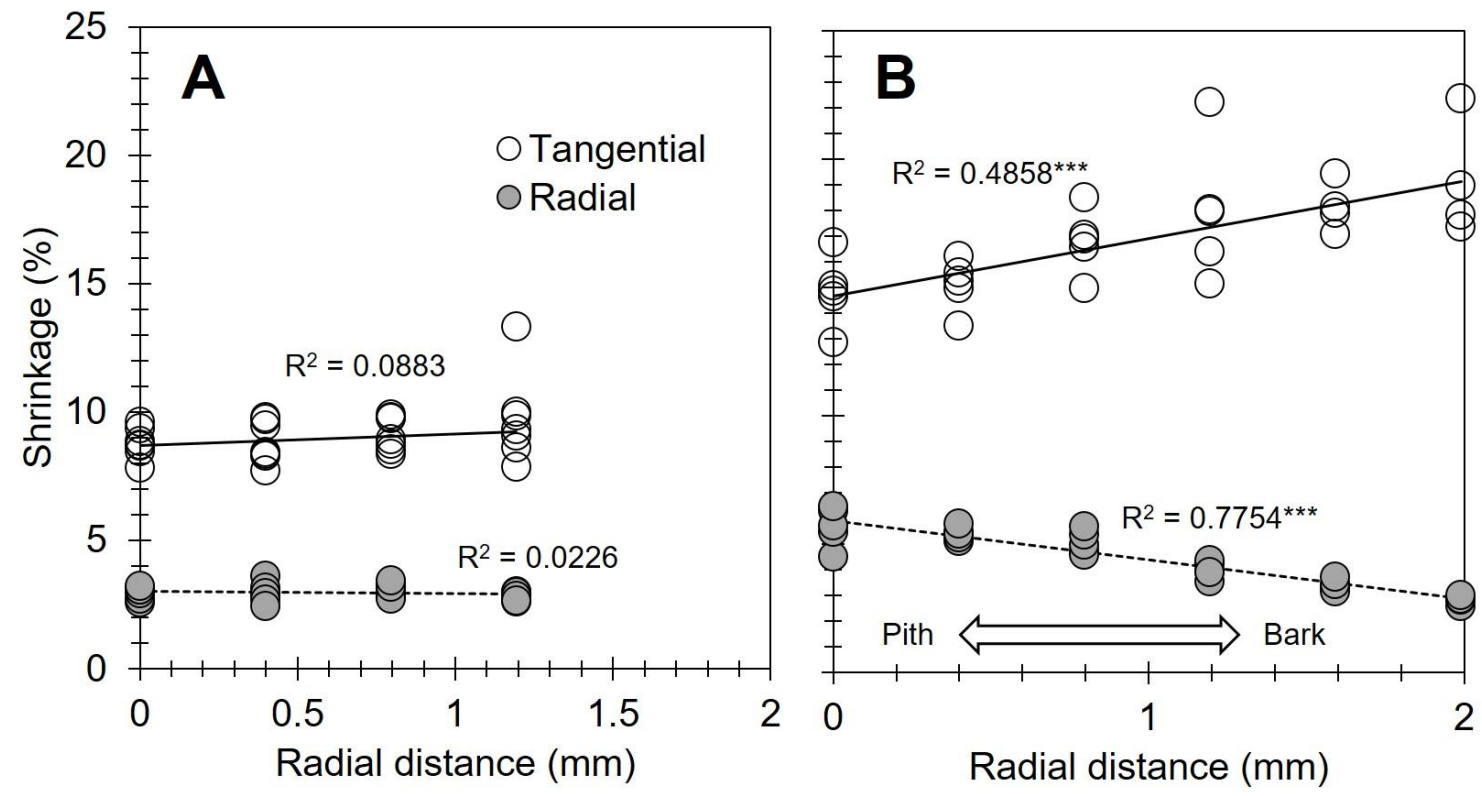

Fig. 8. Tangential and radial shrinkage data (400 $\mu \mathrm{m}$ subset) for air-dried $(A)$ and oven-dried (B) cubes. $R^{2}$ values calculated using the "rFit' package, "***" = significance $>99.9 \%$

As there was a positional gradient, partial correlation analysis was performed adjusting for radial and tangential position ('ppcor' package). The adjusted Spearman coefficients of the measured features are shown in Table 2. Once the radial and tangential position effects were accounted for, there were only a few significant relationships between measured shrinkage and wood morphology. Where the correlation coefficients were significant, higher shrinkage was associated with lower initial cell density (as determined by imaged wall area) and agreed with other studies (Bariska 1992; Lausberg et al. 1995; Shelbourne et al. 2002; McKenzie et al. 2003; Valenzuela et al. 2012; Rebolledo et al. 2013; Ananías et al. 2014; Salvo et al. 2017). 
Both radial and tangential shrinkage were significantly greater further away from vessels (Table 2). This supports the conjecture that during drying, an excess of free water is held within fibre lumens (with restricted free water movement) and not within the vessel lumens and associated paratracheal parenchyma. This allows for water-filled fibre lumens to be adjacent to cell lumens empty of liquid water, allowing for the development of negative water tension and leading to collapse (Dawson et al. 2020). However, it should also be noted that although significant, the correlations between shrinkage and increasing distance to vessels are generally not strong. Visually, cell deformation can also be seen in proximity to vessels (Fig. 4D, F). This indicates appreciable variation in the shrinkage/ collapse response.

There were no significant correlations between shrinkage and the distance to rays. Investigating the association between cells and rays, 180 cells (a total of 90 from each of the air and oven-dried samples) were randomly selected. Thirty four percent of them were immediately adjacent to ray cells. This is broadly in-line with the cell diameters and mean distance to ray data in Table 1, with about a two-cell diameter mean distance from rays. There have been previous observations (Bariska 1992) of shrinkage/collapse being adjacent to ray tissue. That ray tissue plays a significant role in wood hydraulics of living trees is likely (Pfautsch et al. 2015). An analysis of a single tangential section from the airdried sample, showed that $92 \%$ (188/204) of cells could be positively identified as being in contact with at least one ray somewhere along their length. Therefore, there is a close association between the axial elements (fibres) and ray tissue (Fig 9). Observations of direct relationships between fibres and ray cells and how these relate to collapse and checking should be regarded with caution. As checks are also longitudinal features, if they occur at an interface between fibres, then as they extend longitudinally, they are also likely to contact a ray cell. It is, therefore, difficult to distinguish between cause and effect. The correlations in Table 2 are for data that represent averaged distances and are, therefore, more representative of ray frequency, as higher ray frequency means smaller distances to the closest ray.

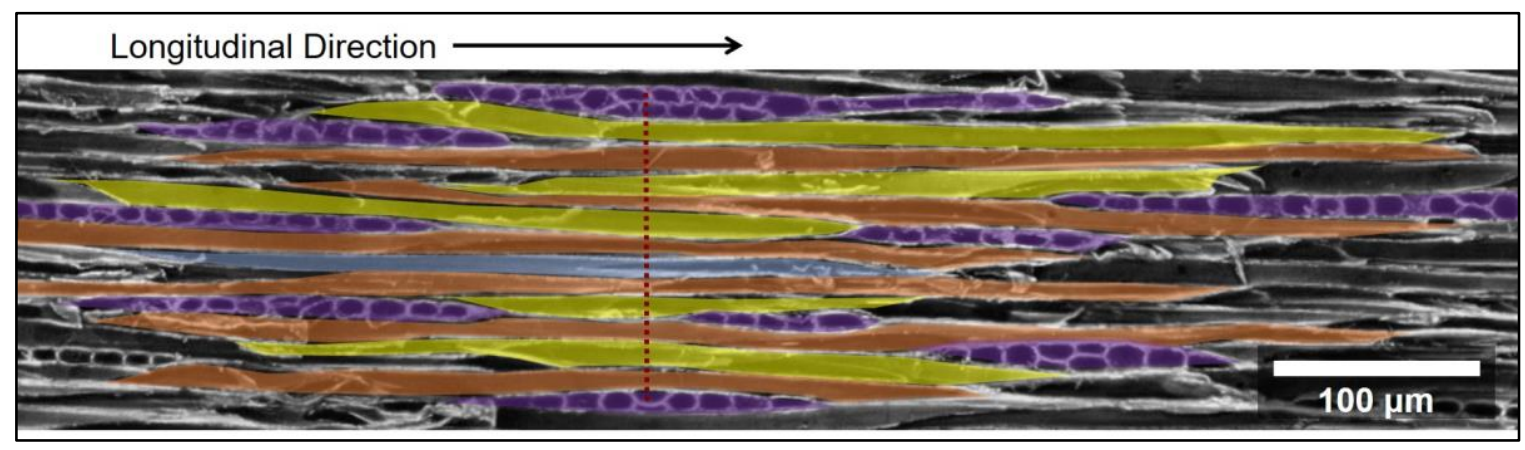

Fig. 9. Tangential longitudinal section showing ray-fibre associations. The red dotted line shows the plane of the transverse face (i.e. the face shown in Fig 4) with few rays (purple) in contact with fibres (alternating yellow and orange). However, all fibres except 1 (pale blue) contact rays along their lengths.

Higher shrinkage showed some relationship with increased cell perimeter and wall area but not wall thickness. The association with lower density means that relative wall perimeter increase is greater than relative wall thickness increase. There was no evidence that collapsed cells had thinner walls. 
Table 2. Partial Spearman Correlation Coefficients Adjusted for Radial and Tangential Position

\begin{tabular}{|c|c|c|c|c|c|c|c|c|}
\hline & \multicolumn{4}{|c|}{ Air-dried, $400 \mu \mathrm{m}$ subset } & \multicolumn{4}{|c|}{ Oven-dried, $400 \mu \mathrm{m}$ subset } \\
\hline & \multicolumn{2}{|c|}{$\begin{array}{l}\text { Tangential } \\
\text { shrinkage }\end{array}$} & \multicolumn{2}{|c|}{$\begin{array}{c}\text { Radial } \\
\text { shrinkage }\end{array}$} & \multicolumn{2}{|c|}{$\begin{array}{l}\text { Tangential } \\
\text { shrinkage }\end{array}$} & \multicolumn{2}{|c|}{$\begin{array}{c}\text { Radial } \\
\text { shrinkage }\end{array}$} \\
\hline Surfaces $(A \& B)$ & $\begin{array}{c}\text { Both }{ }^{1}, \\
n=56\end{array}$ & $\begin{array}{c}\text { Mean }^{2} \\
n=28\end{array}$ & $\begin{array}{l}\text { Both, } \\
n=56\end{array}$ & $\begin{array}{c}\text { Mean, } \\
n=28\end{array}$ & $\begin{array}{l}\text { Both, } \\
n=60\end{array}$ & $\begin{array}{l}\text { Mean, } \\
n=30\end{array}$ & $\begin{array}{l}\text { Both, } \\
n=60\end{array}$ & $\begin{array}{l}\text { Mean, } \\
n=30\end{array}$ \\
\hline Distance to ray & $\stackrel{+}{0.030}$ & $\begin{array}{c}- \\
0.072\end{array}$ & $\begin{array}{c}+ \\
0.147\end{array}$ & $0 . \overline{-}$ & $\begin{array}{c}+ \\
0.173 \\
\end{array}$ & $\begin{array}{c}+ \\
0.337\end{array}$ & $\begin{array}{c}+ \\
0.059\end{array}$ & $\begin{array}{c}+ \\
0.021\end{array}$ \\
\hline $\begin{array}{l}\text { Distance to } \\
\text { vessel }\end{array}$ & $\begin{array}{c}+ \\
0.327 \\
*\end{array}$ & 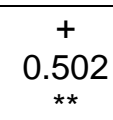 & $\begin{array}{c}++ \\
0.503 \\
* * *\end{array}$ & $\begin{array}{c}+ \\
0.718 \\
* * *\end{array}$ & $\begin{array}{c}+ \\
0.024\end{array}$ & $\begin{array}{c}+ \\
0.136\end{array}$ & $\begin{array}{c}++ \\
0.393 \\
* *\end{array}$ & $\begin{array}{c}+ \\
0.354\end{array}$ \\
\hline Density & $\begin{array}{c}- \\
0.167\end{array}$ & $\begin{array}{c}- \\
0.135\end{array}$ & $\begin{array}{c}- \\
0.355 \\
* *\end{array}$ & $\stackrel{+}{+}$ & $\underset{* *}{0 .}$ & $\underset{*}{-}$ & $\begin{array}{c}- \\
0.643 \\
* * *\end{array}$ & $\begin{array}{c}- \\
0.102\end{array}$ \\
\hline Cell perimeter & $\begin{array}{c}+ \\
0.236\end{array}$ & $0 . \overline{-}$ & $\begin{array}{c}- \\
0.031\end{array}$ & $0 . \overline{-}$ & $\begin{array}{c}+ \\
0.339 \\
* *\end{array}$ & $\stackrel{+}{+}$ & $\begin{array}{c}+ \\
0.294 \\
*\end{array}$ & $0 . \overline{-}$ \\
\hline Cell wall area & $\stackrel{+}{+}$ & $0 . \overline{-}$ & $0 . \overline{-}$ & $0 . \overline{-}$ & $\begin{array}{c}+ \\
0.331 \\
*\end{array}$ & $\stackrel{+}{+}$ & $\begin{array}{c}+ \\
0.204\end{array}$ & $\stackrel{+}{0.001}$ \\
\hline $\begin{array}{l}\text { Cell wall } \\
\text { thickness }\end{array}$ & $\begin{array}{c}+ \\
0.024 \\
\end{array}$ & $\begin{array}{c}+ \\
0.123 \\
\end{array}$ & $\begin{array}{c}- \\
0.143 \\
\end{array}$ & $\stackrel{+}{+}$ & $\begin{array}{c}+ \\
0.072\end{array}$ & $\stackrel{+}{0.044}$ & $\begin{array}{c}- \\
0.133\end{array}$ & $\begin{array}{c}+ \\
0.166\end{array}$ \\
\hline Form parameter & $0 . \overline{-}$ & $\begin{array}{c}+ \\
0.091\end{array}$ & $\begin{array}{c}+ \\
0.015\end{array}$ & $\stackrel{+}{+}$ & 0.305 & $\begin{array}{c}- \\
0.102\end{array}$ & $\begin{array}{c}- \\
0.494 \\
* * *\end{array}$ & $\begin{array}{c}+ \\
0.295\end{array}$ \\
\hline
\end{tabular}

Note: ${ }^{1}$ Data from both transverse surfaces of the cube were used. ${ }^{2}$ The mean of the two surfaces was used. "*" is $>95 \%$, "**" is $>99 \%$, "***" is $\geq 99.9 \%$

In paper products (Dickson et al. 2006) and composites (Dickson et al. 2018) the collapse and deformation of individulaised fibres is related to cell geometry. The strongest correlation between cell dimensions and cell shrinkage was found by using a 'form parameter' to define cell geometry. Form parameter was defined as follows (Reme et al. 1999),

$$
\text { form parameter }=\left[\left(4 \pi W_{a}\right) / C_{p}^{2}\right] \times 100
$$

where $W_{\mathrm{a}}$ is the wall area and $C_{\mathrm{p}}$ is the cell perimeter. Cells with a low form parameter have large perimeters relative to cell wall thickness.

Overall, once radial and tangential position effects were removed, the few significant relationships found suggest that increased shrinkage is related to lower cell density, increased distance between vessels, and cells with large perimeters relative to cell wall thickness.

\section{CONCLUSIONS}

1. There were two levels of positional relationships between wood morphology and shrinkage.

- There was a strong relationship between radial position and shrinkage; evidence was especially strong for the oven-dried sample, with a shrinkage gradient across 
the imaged region. In this case there was a strong region of wood collapse/ deformation outward (towards the bark side) from the imaged area. This is a relationship with a feature out of the region of interest, that couldn't be characterised. This position effect combined with the strong correlation between shrinkage on both surfaces of the cube, suggests that the shrinkage and collapse seen in the oven-dried sample is a global and not a local phenomenon. More extensive imaging, over larger areas are required to capture in the initiation of the collapse event in this situation.

- There were also position relationships with morphological features, such as the distance to a ray or vessel element. Both the air and oven-dried cubes showed significant relationships of increased shrinkage further away from vessel elements. Averaging the ray and vessel distance data represents the relative frequency of rays and vessels. At the fibre level, it was shown that most were in contact with a ray somewhere along their length.

2. The second relationship is at the cellular level. This was seen in the significant relationship between shrinkage and density (higher shrinkage related to lower density). However, cell dimensions of individual cells showed only weak relationships with shrinkage and collapse.

3. The approach combining DIC with image analysis, over areas $>3 \mathrm{~mm}^{2}$ was successful and averaging the data over larger areas meant individual cell effects were lost but the strength of the correlations was often improved.

\section{ACKNOWLEDGMENTS}

The authors thank Lloyd Donaldson, Diego Elustondo, Mark Riddell, and Mathias Sorieul for their useful comments. This work was supported by SSIF funding provided by the New Zealand Ministry of Business, Innovation \& Enterprise (MBIE).

\section{REFERENCES CITED}

Almeida, G., Huber, F., and Perré, P. (2014). "Free shrinkage of wood determined at the cellular level using an environmental scanning electron microscope," Maderas: Ciencia y Tecnologia 16(2), 187-198. DOI: 10.4067/S0718-221X2014005000015

Ananías, R. A., Sepúlveda-Villarroel, V., Pérez-Peña, N., Leandro-Zuñiga, L., SalvoSepúlveda, L., Salinas-Lira, C., Cloutier, A., and Elustondo, D. M. (2014). "Collapse of Eucalyptus nitens wood after drying depending on the radial location within the stem," Drying Technology 32(14), 1699-1705. DOI: 10.1080/07373937.2014.924132

Badel, E., Bakour, R., and Perré, P. (2006). "Investigation of the relationships between anatomical pattern, density and local swelling of oak wood," IAWA Journal 27(1), 55-71. DOI: 10.1163/22941932-90000137

Badel, E., and Perré, P. (2001). "Using a digital X-ray imaging device to measure the swelling coefficients of a group of wood cells," NDT and E International 34(5), 345353. DOI: 10.1016/S0963-8695(00)00072-4

Badel, E., and Perré, P. (2007). "The shrinkage of oak predicted from its anatomical 
pattern: Validation of a cognitive model," Trees - Structure and Function 21(1), 111120. DOI: $10.1007 / \mathrm{s} 00468-006-0105-\mathrm{z}$

Bariska, M. (1992). "Collapse phenomena in eucalypts," Wood Science and Technology 26(3), 165-179. DOI: 10.1007/BF00224290

Blackburn, D., Hamilton, M., Harwood, C., Innes, T., Potts, B., and Williams, D. (2010). "Stiffness and checking of Eucalyptus nitens sawn boards: Genetic variation and potential for genetic improvement," Tree Genetics and Genomes 6(5), 757-765. DOI:10.1007/s11295-010-0289-7

Boutelje, J. B. (1962). "The relationship of structure to transverse anisotropy in wood with reference to shrinkage and elasticity," Holzforschung 16(2), 33-46. DOI: 10.1515/hfsg.1962.16.2.33

Carrillo, I., Aguayo, M. G., Valenzuela, S., Mendonça, R. T., and Elissetche, J. P. (2015). "Variations in wood anatomy and fiber biometry of Eucalyptus globulus genotypes with different wood density," Wood Research 60(1), 1-10.

Dawson, B., Pearson, H., Kimberley, M. O., Davy, B., and Dickson, A. R. (2020). "Effect of supercritical $\mathrm{CO}_{2}$ treatment and kiln drying on collapse in Eucalyptus nitens wood," European Journal of Wood and Wood Products 78(2), 209-217. 10.1007/s00107-020-01500-5

Derome, D., Griffa, M., Koebel, M., and Carmeliet, J. (2011). "Hysteretic swelling of wood at cellular scale probed by phase-contrast X-ray tomography," Journal of Structural Biology 173(1), 180-190. DOI: 10.1016/j.jsb.2010.08.011

Derome, D., Rafsanjani, A., Hering, S., Dressler, M., Patera, A., Lanvermann, C., Sedighi-Gilani, M., Wittel, F. K., Niemz, P., and Carmeliet, J. (2013). "The role of water in the behavior of wood," Journal of Building Physics 36(4), 398-421. DOI:10.1177/1744259112473926

Dickson, A. R., Corson, S. R., and Dooley, N. J. (2006). "Fibre collapse and decollapse determined by cross-sectional geometry," Journal of Pulp and Paper Science 32(4), 205-209.

Dickson, A., Nanayakkara, B., Sellier, D., Meason, D., Donaldson, L., and Brownlie, R. (2017). "Fluorescence imaging of cambial zones to study wood formation in Pinus radiata D. Don," Trees - Structure and Function 31(2), 479-490. DOI: 10.1007/s00468-016-1469-3

Dickson, A. R., and Sandquist, D. (2018). "Mode of wood fibre breakage during thermoplastic melt processing," Composites Part A: Applied Science and Manufacturing 112, 496-503. DOI: 10.1016/j.compositesa.2018.07.004

Groom, L., Mott, L., and Shaler, S. (2002). "Mechanical properties of individual southern pine fibers. Part I. Determination and variability of stress-strain curves with respect to tree height and juvenility," Wood and Fiber Science 34(1), 14-27.

Hamilton, M. G., Raymond, C. A., Harwood, C. E., and Potts, B. M. (2009). "Genetic variation in Eucalyptus nitens pulpwood and wood shrinkage traits," Tree Genetics and Genomes. 5(2), 307-316. DOI: 10.1007/s11295-008-0179-4

Han, Y., Park, Y., Park, J. H., Yang, S. Y., Eom, C. D., and Yeo, H. (2016). “The shrinkage properties of red pine wood assessed by image analysis and near-infrared spectroscopy," Drying Technology 34(13), 1613-1620. DOI: 10.1080/07373937.2016.1138964

Hauke, J., and Kossowski, T. (2011). "Comparison of values of Pearson's and Spearman's correlation coefficients on the same sets of data," Quaestiones Geographicae 30(2), 87-93. DOI: 10.2478/v10117-011-0021-1 
Innes, T. C. (1996). "Collapse and internal checking in the latewood of Eucalyptus regnans F. Muell," Wood Science and Technology 30(6), 373-383. DOI: $0.1007 / \mathrm{BF} 00244434$

Kang, C. W., Muszyński, L., Hong, S. H., and Kang, H. Y. (2016). "Preliminary tests for the application of an optical measurement system for the development of a kilndrying schedule," Drying Technology 34(4), 483-490. DOI: 10.1080/07373937.2015.1060604

Kim, S. (2015) "ppcor: An R package for a fast calculation to semi-partial correlation coefficients," Communications for Statistical Applications and Methods 22(6), 665674. DOI: 10.5351/CSAM.2015.22.6.665

Kloke, J. D., and McKean, J. W. (2012). "Rfit: Rank-based estimation for linear models," The R Journal. 4(2), 57-64. DOI: 10.32614/rj-2012-014

Kube, P. D., and Raymond, C. A. (2005). "Breeding to minimise the effects of collapse in Eucalyptus nitens sawn timber," Forest Genetics 12(1), 23-34.

Lanvermann, C., Wittel, F. K., and Niemz, P. (2014). "Full-field moisture induced deformation in Norway spruce: Intra-ring variation of transverse swelling," European Journal of Wood and Wood Products 72(1), 43-52. DOI: 10.1007/s00107-013-0746-8

Lausberg, M. J. F., Gilchrist, K. F., and Skipwith, J. H. (1995). "Wood properties of Eucalyptus nitens grown in New Zealand," New Zealand Journal of Forestry Science. 25(2), 147-63.

Lee, S. S., and Jeong, G. Y. (2018). "Effects of sample size on swelling and shrinkage of Larix kaempferi and Cryptomeria japonica as determined by digital caliper, image analysis, and digital image correlation (DIC)," Holzforschung 72(6), 477-488. DOI: 10.1515/hf-2017-0120

McKenzie, H. M., Shelbourne, C. J. A., Kimberley, M. O., McKinley, R. B., and Britton, R. A. J. (2003). "Processing young plantation-grown Eucalyptus nitens for solidwood products. 2: Predicting product quality from tree, increment core, disc, and 1-M billet properties," New Zealand Journal of Forestry Science 33(1), 79-113.

Murata, K., Ito, M., and Masuda, M. (2001). "An analysis of the swelling behavior of various woods using an optical microscope and a digital image correlation method (DIC)," Zairyo/Journal of the Society of Materials Science, Japan 50(4), 397-402. DOI: $10.2472 /$ jsms.50.397

Patera, A., Van den Bulcke, J., Boone, M. N., Derome, D., and Carmeliet, J. (2018). "Swelling interactions of earlywood and latewood across a growth ring: Global and local deformations," Wood Science and Technology 52(1), 91-114. DOI: 10.1007/s00226-017-0960-3

Perré, P., Almeida, G., Ayouz, M., and Frank, X. (2016). "New modelling approaches to predict wood properties from its cellular structure: Image-based representation and meshless methods," Annals of Forest Science 73(1), 147-162. DOI: 10.1007/s13595015-0519-0

Perré, P., and Hubber, F. (2007). "Measurement of free shrinkage at the tissue level using an optical microscope with an immersion objective: Results obtained for Douglas fir (Pseudotsuga menziesii) and spruce (Picea abies)," Annals of Forest Science 64(3), 255-265. DOI: 10.1051/forest:2007003

Pfautsch, S., Hölttä, T., and Mencuccini, M. (2015). "Hydraulic functioning of tree stems - Fusing ray anatomy, radial transfer and capacitance," Tree Physiology 35(7), 706722. DOI: $10.1093 /$ treephys/tpv058

Rebolledo, P., Salvo, L., Contreras, H., Cloutier, A., and Ananias, R. A. (2013) 
"Variation of internal checks related to anatomical structure and density in Eucalyptus nitens wood," Wood and Fiber Science 45(3), 279-286.

Redman, A.L., Bailleres, H., Turner, I., and Perre, P. (2016). "Characterisation of woodwater relationships and transverse anatomy and their relationship to drying degrade," Wood Science and Technology 50(4), 739-757. DOI: 10.1007/s00226-016-0818-0

Reme, P. A., Johnsen, P. O., and Helle, T. (1999). "Changes induced in early- and latewood fibres by mechanical pulp refining," Nordic Pulp and Paper Research Journal 14(3), 256-262.

Ridoutt, B. G., and Sands, R. (1993). "Within-tree variation in cambial anatomy and xylem cell differentiation in Eucalyptus globulus," Trees - Structure and Function 8(1), 18-22. DOI: 10.1007/BF00240977

Saalfeld, S. (2010). "Enhance local contrast (CLAHE)", (http://fiji.sc/Enhance_Local_Contrast_\%28CLAHE\%29\#).

Salvo, L., Leandro, L., Contreras, H., Cloutier, A., Elustondo, D. M., and Ananías, R. A. (2017). "Radial variation of density and anatomical features of Eucalyptus nitens trees," Wood and Fiber Science 49(3), 301-311.

Schneider, C. A., Rasband, W. S., and Eliceiri, K. W. (2012). "NIH Image to ImageJ: 25 years of image analysis," Nature Methods 9(7), 671-675. DOI: 10.1038/nmeth.2089

Shelbourne, C. J. A., Nicholas, I. D., McKinley, R. B., Low, C. B., McConnochie, R. M., and Lausberg, M. J. F. (2002). "Wood density and internal checking of young Eucalyptus nitens in New Zealand as affected by site and height up the tree," New Zealand Journal of Forestry Science 32(3), 357-385.

Thévenaz, P., and Unser, M. (2007). "User-friendly semiautomated assembly of accurate image mosaics in microscopy," Microscopy Research and Technique 70(2), 135-146. DOI: 10.1002/jemt.20393

Valenzuela, P., Bustos, C., Lasserre, J. P., and Gacitúa, W. (2012). “Caracterización nanomecánica de la estructura celular y anatómica de Eucalyptus nitens y su relación con la frecuencia de grietas y rajaduras en madera redonda," Maderas. Ciencia y tecnología 14(3), 321-327. DOI: 10.4067/s0718-221x2012005000006

Wu, Y.-Q., Hayashi, K., Liu, Y., Cai, Y., and Sugimori, M. (2006). "Relationships of anatomical characteristics versus shrinkage and collapse properties in plantationgrown eucalypt wood from China," Journal of Wood Science 52(3), 187-194. DOI: 10.1007/s10086-005-0751-6

Article submitted: April 13, 2020; Peer review completed: June 13, 2020; Revised version received: June 17, 2020; Accepted: June 19, 2020; Published: June 24, 2020. DOI: 10.15376/biores.15.3.6149-6164 